\title{
Between the Bittern and the Café du Monde: Paul Muldoon's The Prince of the Quotidian ${ }^{1}$
}

Paul Muldoon's poetry has long been infused with references to his life, raising the issue of the relation between the lived experience and its textual representations. It may be noted that Muldoon's poetry departs from a Derridean premise. In Shibboleth: For Paul Celan, Derrida focuses on the notion of date, arguing that dating a poem, on the one hand, places it at a uniquely singular moment in time but, on the other, "to speak of it, one must also efface it, make it readable, audible, intelligible beyond the pure singularity of which it speaks" 2 . Therefore, shibboleth is no cypher behind which a moment from the past lies hidden; instead, it is a word-key to multifarious repetitions of the date, repetitions in which the now-effaced originary moment of inscription becomes a fiction due to the fact that the date "is not exactly the same but rather analogic to the other, and that is because the original date, as an encoded mark of the other here and now, was a kind of fiction in the first place, claiming its singularity solely thanks to fables of conventions and generalisations" ${ }^{\prime 3}$. To assume that Muldoon's autobiographical references point to a singular moment in time or a particular person is tantamount to falling prey to the trap of "conventions and generalisations".

In "Twice" (from The Annals of Chile, 1994), the autobiographical element is exposed in a manner that resembles the double-bind of dating

* Uniwersytet Łódzki, Wydział Filologiczny, Instytut Anglistyki, Zakład Literatury i Kultury Brytyjskiej, e-mail: witpietrzak@wp.pl.

${ }^{1}$ The article has been written within the framework of the project financed by The National Science Centre, Cracow, Poland, pursuant to the decision number DEC 2017/25/B/ HS2/02099.

2 J. Derrida, Acts of Literature, ed. D. Attridge, Routledge, New York 1992, p. 382.

${ }^{3}$ In the absence of an English translation of the passage from Schibboleth pour Paul Celan, I pivot-translate from the Polish edition, Szibbolet dla Paula Celana, trans. A. Dziadek, Fa-art, Bytom 2000, p. 53. 
that Derrida describes in Shibboleth. The speaker remembers an episode from his school years when along with his two friends Taggart and McAnespie they "sawed and sawed" a frozen "sod of water" until "we were somehow able to manoeuvre / out and, finally, stand on its side" . Then the speaker looks through the ice chunk and sees another colleague, the left-handed prankster "Lefty" Clery "grinning from both ends of the school photograph, / having jooked behind the three-deep rest of us to meet the Kodak's / leisurely pan; 'Two places at once, was it, or one place twice?'" 5 . Availing himself of the opportunity given by the narrow-angle camera, "Lefty" Clery runs from one side of the group, positioned to be photographed, to the other, as a result appearing twice in the class picture. The speaker's question, asked with hindsight, if it was "Two places at once $[\ldots]$ or one place twice" problematises what initially seems a direct evocation of his teenage years. While it appears that the moment Taggart, McAnespie and the speaker were sawing the sod is recalled as an instant of particularity, the later image of Clery reappearing on the school photo calls up the process of proliferation of representations of presence that even such an ostensibly realist device as the camera necessarily participates in. The recollection of an event from the past is thus susceptible of the question whether these are two moments at once - the experiential event existing in the moment passed and the textual recollection existent in the moment of iteration of the poem - or that same moment twice - then in the past and now in the moment of iteration. In both cases what appears to be a direct summoning of the past becomes an even of duplication and internal bifurcation between the moment of occurrence and the instant of iteration.

In Muldoon's growing corpus of works, however, there is a collection of lyrics that takes the idea of poetic autobiography rather overtly. The Prince of the Quotidian (1994) is a record of January 1992, when Muldoon decided to write a poem a day, recording his everyday living in his new-found home in New Jersey. While most critics agree that The Prince of the Quotidian is among Muldoon's less important work ${ }^{6}$, the pamphlet does raise important questions about the relation between the lived experience and the textual representation. As has been suggested, Muldoon's work is often acutely aware of the difficulty of recording factual events in verse, this awareness though is perhaps nowhere better felt than in The Prince of the Quotidian. Given that he has identified the pamphlet as a diary, the tension between the singularity of the lived experience and textual multiplying iterability becomes manifest.

The most salient motif, which recurs throughout the volume, is that of the journey. The first of 14 full and 15 "stumped" sonnets, which opens the pamphlet, describes a morning excursion "After breakfast with Belinda and

${ }^{4}$ P. Muldoon, Poems, Faber, London 2001, p. 330-331.

${ }^{5}$ P. Muldoon, Poems, p. 331.

${ }^{6}$ Seamus Heaney refers to the pamphlet as "Muldoodles" as opposed to his major work, which he terms "Mulboons". Quoted in T. Kendal, Paul Muldoon, Seren, Brigend 1996, p. 192. See also C. Wills, Reading Paul Muldoon, Bllodaxe, Newcastle upon Tyne 1998. 
Philp Haas"7. Elsewhere we follow the speaker drive to the Opera (PQ, 18), past the streets of Loyola and Tulane (PQ, 26) and down "An alley of live oaks festooned with Spanish moss" (PQ, 27). The majority of these trips is evoked in the present tense, as though we were made privy to the poet's thoughts while he is travelling, which emphasises the simultaneity of the singular life and equally singular writing. However, the motif of journey is a heavy presence across the tradition of Western poetry, beginning with the Odyssey, a text not without its significance for Anglo-Irish literature. The mundane episodes from the speaker's life, which enter the focus of The Prince of the Quotidian, resemble the similarly run-of-the-mill events that Stephen Dedalus walks through on 16 June, 1904. The parallels between Dedalus and Muldoon's speaker extend further, from the incidental appearance of a fearsome $\operatorname{dog}^{8}$, to the self-scolding for the failure to pay respect to the mother figure. In the last poem, the speaker is slapped across the cheek and chastised by "the horse-head", a typically Muldoonian image of the poet's alter ego, "Above all else, you must atone / for everything you've said and done / against your mother" (PQ, 41). This is an echo of Buck Mulligan's reproach to Stephen: "You could have knelt down, damn it, Kinch when your dying mother asked you. [...] to think of your mother begging you with her last breath to kneel down and pray for her. And you refused. There is something sinister in you..." ${ }^{\prime 2}$. Bearing in mind those similarities to Ulysses, the motif of journey assumes a similarly suggestive nature in Muldoon's sequence. The speaker travels in his world, between his house in New Jersey and the Opera house in New York or his office at Princeton, where he teaches, but the moment of inscription endows those singularly unique excursions with mythical proportions, as a result turning the words of the poems away from logos and close to mythos.

At one point in The Prince of the Quotidian, the speaker recalls "grading papers from the seminar I taught" (PQ, 24). Among the text that are alluded to in this sonnet is Immram Curaig Mael Duin, most likely an $8^{\text {th }}$ century poem of voyage that the titular Mael Duin undertook in search of the murderers of his father. Imrama are classic Irish voyage poems that will typically take the hero West, to the land of the dead, where he will learn wisdom only to come back, thus edified, to his native place. The name of Mael Duin sounds beguilingly similar to Muldoon and the poet employed the narrative of Imrama in his own version of the poem entitled plainly "Immram" (from Why Brownlee Left?, 1980). In preference to an old Irish setting, "Immram" is set in Los Angeles of Raymond Chandler's era, where a hardboiled protagonist, akin to Philip Marlowe, tries to untangle the mystery of his father's disappearance. In The Prince of the Quotidian, there is no place for such exploits, however, nor do the sonnets describe as grim and malleable a place as Chandler's LA, instead the speaker is shown to be a comfortable middle-class intellectual with a penchant for snappish remarks both about

${ }^{7}$ P. Muldoon, The Prince of the Quotidian, Gallery Press, Oldcastle 1994, p. 11. Henceforth cited in text as PQ with page number.

${ }^{8}$ See PQ, 13 and J. Joyce, Ulysses, Shakespeare and Company, Paris 1922, p. 45.

${ }^{9}$ J. Joyce, Ulysses, p. 5. 
art (the opera he goes to watch proves "so terminally bouffe / even the Montgolfier's hot-air balloon / seems a leaden leitmotif" (PQ, 18) and his friends (he jeers at "Doctor" Seamus Heaney, "the great physician of the earth" who "is waxing metaphysical" (PQ, 14). And yet the speaker remains restlessly in movement, though he hardly leaves New Jersey, his thoughts ramble far and wide, as he agonises over his "long-lost cousin, Marina" $(P Q, 15)$ or Kevin McKearney (PQ, 23), shot dead in County Tyrone by loyalist paramilitaries during the Troubles. As Clair Wills observes, "Part of the point [in The Prince of the Quotidian] is surely that you can be anywhere in your imagination" but Muldoon, she adds, goes further by implying that "imagination renders travel redundant"10. While she qualifies her claim, Wills does point out a crucial element in The Prince of the Quotidian when she addresses the notion of imaginary travel, for the series of poems is indeed a journey as much across Muldoon's daily routines as across a panorama of Irish and American culture. While in Immram Curaig Mael Duin, the hero meets supernatural creatures, from horse-like beasts to demons, in The Prince of the Quotidian, the speaker encounters less unusual figures. Nevertheless, the mythical undertones are discernible, making the quotidian an occasionally rather sinister place.

Despite its air of light-heartedness, there are moments in the series when unexpectedly violence interrupts the serene idyll of the poet and his wife Jean. At first, at a get-together, one of the guests, Louise, and Jean become aware that "something has sickened / and died under the dining-room floor" (PQ, 15). Although this rather nightmarish image is not developed at length, death and decay have been admitted in the quaint cityscapes of the poems. Several lyrics on, the speaker confesses: "I'm filled with dismay / by news of two murders in the Moy" (PQ, 19). The murders are those of Kevin McKearney and his uncle, and the poem registers the tragic curtailment of life by terminating abruptly after only two lines. Since the dominating form in the pamphlet is sonnet and the two-liner informing of McKearney's death is preceded by two perfect sonnets, the compactness of the lyric, which includes only four words except the sentence quoted above: "Weehawken. Kearney. The Oranges" (PQ, 19), seems to represent the speaker's being lost for words. A few poems later, the speaker reveals that the deaths keep haunting him:

I open the freezer. The blood-besmirched

face of Kevin McKearney

implores me from a hospital gurney;

"Won't you at least visit my grave in March?" (PQ, 23).

This again resembles a curtailed sonnet in that the quartet rhymes ABBA, suggesting that another quartet should follow but the words of the recently murdered McKearney stop the speaker in his tracks, as he once more is left gasping for words. Such a visitation of a ghost that is begging the speaker to pay it the last honour is again an image rooted in the tradition

${ }^{10}$ C. Wills, Reading Paul Muldoon, p. 164. 
of English-language poetry, with Shakespeare being perhaps the steeple of the haunted poets. The implication that the speaker ought to render some last service to the ghost rather blatantly alludes to Hamlet. One may also cite the entire graveyard strain of Romanticism, starting pre-emptively with Thomas Gray and raising to prominence in Wordsworth, who not only had ghosts populate his poems but also wrote a series of "essays upon epitaphs". Still, what immediately strikes in Muldoon's poem is a jump-scare nature of the image of the talking head in the freezer, which has been popularized by the modern horror genre in cinema. In Muldoon, it is not an entire ghost but just a fragment that puts in an appearance. This is not without its implication for the form of the poem, which is after all a fragmented sonnet. While it may be argued that Muldoon openly plays with tradition of haunted poetry, his rendition of the motif stresses the uncanny and untimely nature of the visitation.

To return to the binary of singularity and iterative repetition, one may notice that the sonnets and part-sonnets in The Prince of the Quotidian refer to unique moments in the speaker's life but their poetic implementation stresses their overtly traditional nature. While the particular visit of the Haases to the Muldoon-Korelitz may have taken place only once, the sonnet that describes the event shifts the place of the singular episode to the plane of iterative repetition. Derrida insisted that each time a poem is read it becomes a medial point between the reader and the other of the poem, a point where the date of reading and the date of writing coalesce without ever becoming the same date. This tension between originary moment in the past and the reworking of the moment in language reappear in the scheme of The Prince of the Quotidian in that the events the sonnets allude to are only available as tropes, which Muldoon subtly suggests by working them into a network of intertextual allusions to Anglo-Irish and British traditions. Though the journeys are singular, the echoes of Imrama shift the emphasis from their uniqueness to their textual recursiveness. Even if the death of people who were close to the poet is personalised, the haunting images are positioned in the context evocative of Shakespeare and Romanticism. It seems that the harder Muldoon tries to identify the actual singular context for his poems, the more pluralist in their net of associations and intertextual contexts those poems become.

This tension between singular past and iteratively deferred present is focused on in the central sonnet of the entire series, in which the speaker casts his thoughts to his newly-born nephew:

"Let him", I heard, "let him be one ignited by the quaint

in this new quotidian: a mound

of coffee beans in the 'Café du Monde';

the New Orleans School of Cookery's

okra-

monious gumbo; a dirigible of Paul Prudhomme

floating above the Superdome;

let the Prince of the Quotidian lead an alligator 
along the banquette of Decatur

yet let him not, with Alejandro O'Reilly,

forget the cries of the bittern and the curlew" (PQ, 26).

This is a prayer for the nephew in the manner of W.B. Yeats's two prayers, particularly that for his daughter, in which Yeats imagines her future as "accustomed, ceremonious"11. Whereas Yeats desires that she should remain rooted in "one dear perpetual place"12, Muldoon hopes that Dillon will grow up to inherit "the new quotidian" of internationalism and become one of those grains to be found in the mound at the "Cafe du Monde". At the same time he expresses a more traditionalist desire that Dillon should not "forget the cries of the bittern and the curlew". Wills usefully point out that "these birds, like the corncrake, have tremendous resonances in Irish literature"13. In the light of this fact, Muldoon wishes Dillon might negotiate the path between internationalism and traditionalism, even as he suggests that neither side is without its demerits. After all, the internationalist references sound like oddities whereas the reference to Alejandro O'Reilly subverts the "quaint" connotations of Irish role in the history of colonisation. As a mid-eighteenth century Irish mercenary who made inroads into Louisiana and New Orleans, fighting for Spain, a Catholic and Royalist state, Alejandro O'Reilly seems to embody not the oppressed Irishman, suffering at the hands of the ruthless England, but the Irish conquistador, for whose achievements Spanish King Charles III conferred on him the governorship of Cuba. Therefore what Muldoon implies here is that "this new quotidian" has emerged from a history that is not free from its darker episodes and immigrants to the US, while constitutive of this superbly interesting melting pot, brought as much variety as the Old World violence and brutality.

"The Prince of the Quotidian", as he is imagined in the middle sonnet in the figure of the new-born Dillon, becomes a metonym for the eclectic culture that Muldoon sports throughout the pamphlet. As the speaker traipses across the city, he casually mentions Irish poets, critics and musicians. Among many others there are Irishmen and Irishwomen: Yeats, Heaney, Derek Mahon (a little disingenuously mentioned with reference to his alcohol problem), Michael Longley, Seamus Deane (derided for his suggestion that Muldoon is "in exile" in New Jersey), Nuala Ni Dhomhaill and Medbh McGuckian, U2 and Van Morrison; Americans: Satchmo - Louis Armstrong, Oliver Stone and Warren Zevon - both friends with Muldoon also make an appearance. It is important, however, that the speaker never fails to balance the numerous cultural and artistic affiliations between Ireland and the USA so that, as Jonathan Bolton asserted, this "assorted blend of cultural references, personal experiences, and multilingual words and phrases [...] seeks to

${ }^{11}$ W.B. Yeats, The Collected Poems of W.B. Yeats, ed. R.J. Finneran, Scribner, New York 1996, p. 190.

\footnotetext{
${ }^{12}$ W.B. Yeats, The Collected Poems..., p. 189.

${ }^{13}$ C. Wills, Reading Paul Muldoon, p. 165.
} 
unify and reconcile, through formal and experiential repetitions and the use of temporal and spatial dislocations, Muldoon's Northern Irish past with his extranational, 'hybrid' present. The result, paradoxically, is an attempt to retain national identity while at the same time to liberate from such narrow identity formations"14. What The Prince of the Quotidian offers is, on the one hand, a plurality of viewpoints and deferral of assertions of identity, what Kendall calls "varied, beautiful and downright bizarre quotidian life"15, and, on the other, an implication of inescapable singularity of experience, both national and individual.

The many affinities that Muldoon cites throughout the pamphlet seem to display a contrary progression in that for example mentioning "Doctor" Heaney who "has taken to 'walking on air'", the speaker sends his poem spiralling centrifugally towards Heaney's own work of the time as well as to the source of the quotation. In his 1989 collection of essays The Place of Writing, Heaney observes of Muldoon's work to date: "[his] swerves away from any form of poker-faced solidarity with the political programs of the Northern Catholic minority (from which he hails) have kept him so much on his poetic toes that he has practically achieved the poetic equivalent of walking on air"16. In his treatment of Muldoon, Heaney "sounds almost envious" $^{\prime 17}$ of the younger poet's ability to write outside the cultural background of Northern Irish conflicts and polarities, as if his words were coming straight from the Muse's mouth. In The Spirit Level, Heaney's 1996 volume, there are poems like "Tollund", in which the speaker rambles across fields and concludes that "it was user-friendly outback / Where we stood footloose, at home beyond the tribe"18. This is no longer the place in which the speaker declares he "will feel lost, / Unhappy and at home"19, as he put in "The Tollund Man" from Wintering Out (1972). The speaker may admit that he and his companion are "More scouts than strangers, ghosts who'd walked abroad / Unfazed by light" ${ }^{20}$, but he recognises that Tollund, as evoked in his poem, is a place outside the tribal wars that in 1994, when the poem was written, were slowly coming to an end. It is poems like "Tollund" that Muldoon's speaker seems to have in mind when he claims that Heaney is "walking on air".

Muldoon's offhand remark about Heaney in The Prince of the Quotidian points out to this extratextual information but also works centripetally, reaching afar into the cultural repository of allusions only to focus those allusions back on the poem in hand. Heaney's diagnosis of Muldoon's apolitical work is what The Prince of the Quotidian is all about, even if Muldoon

${ }^{14} \mathrm{~J}$. Bolton, Irish Stew at the Café du Monde: Heterogeneity and the Émigré Experience in Paul Muldoon's “Yarrow", „South Atlantic Review" 1991, no. 64.1, p. 52.

${ }^{15}$ T. Kendall, Paul Muldoon, Seren, Brigend 1996, p. 199.

${ }^{16}$ S. Heaney, The Place of Writing, Scholars' Press, Atlanta 1989, p. 42.

${ }^{17}$ E. Kennedy-Andrews, Writing Home: Poetry and Place in Northern Ireland, 1968-2008, Brewer, Cambridge 2008, p. 98.

${ }^{18}$ S. Heaney, The Spirit Level, Faber, London 1996, p. 69.

${ }^{19}$ S. Heaney, Wintering Out, Faber, London 1972, p. 48.

${ }^{20}$ S. Heaney, The Spirit..., p. 69. 
feels that not taking a firm stand on any side does not in itself solve the difficulty of an artist coming from a politically torn country. What is crucial, it appears, is that the poet remain on alert for various threats that lie about: from too easy an acceptance of the mundane, which may become poetically stifling (pace Kendall), to sentimental attitude to national history, which by no means records only suffering at the hands of the foreign oppressor.

As centripetal singularity yields to centrifugal multiplicity spurred on by iterative intensification of the play of signs, and conversely, Muldoon opens up vistas of problematic exchanges between the drive towards uniqueness of experience and towards multiplicity of textual reproduction of that experience. This, in turn, brings powerful resonances for our understanding of autobiography, since Muldoon offers poetic autobiography in the form of a map of the cultural, social and aesthetic network in which one functions. The individual cannot but be defined through his or her longitudinal and latitudinal connections to the other parts of the worldscape, which both string out the self until it becomes a haze, more a trope than a presence, and at the same time help to pinpoint the location of this self, even as it remains perpetually elusive.

\section{B I B LIOG R A PHY}

Bolton J., Irish Stew at the Café du Monde: Heterogeneity and the Émigré Experience in Paul Muldoon's "Yarrow", „South Atlantic Review" 1999, no. 64, p. 48-71.

Derrida J., Acts of Literature, ed. D. Attridge, Routledge, New York 1992.

Derrida J., Szibbolet dla Paula Celana, trans. A. Dziadek, Fa-art., Bytom 2000.

Heaney S., The Place of Writing, Scholars' Press, Atlanta 1989.

Heaney S., The Spirit Level, Faber, London 1996.

Heaney S., Wintering Out, Faber, London 1972.

Joyce J., Ulysses, Shakespeare and Company, Paris 1922.

Kendal T., Paul Muldoon, Seren, Brigend 1996.

Kennedy-Andrews E., Writing Home: Poetry and Place in Northern Ireland, 1968-2008, Brewer, Cambridge 2008.

Muldoon P., Poems, Faber, London 2001.

Muldoon P., The Prince of the Quotidian, Gallery Press, Oldcastle 1994.

Wills C., Reading Paul Muldoon, Bloodaxe, Newcastle upon Tyne 1998.

Yeats W.B., The Collected Poems of W.B. Yeats, ed. R.J. Finneran, Scribner, New York 1996. 


\section{SUMMARY}

The article focuses on Paul Muldoon's 1994 collection The Prince of the Quotidian. The pamphlet is regarded as a poetic autobiography that takes its impetus from a dual drive towards particularising of experience on the one hand and iterative multiplication of its textual representation. Taking cue from Derrida's Shibboleth: For Paul Celan, I argue that Muldoon sets up a network of connection that his speaker functions within, thereby positioning himself on the threshold between centripetal focus on life, however mundane it should be, and centrifugal textuality, motivated by intertextual references.

\section{Keywords}

Paul Muldoon, autobiography, contemporary Irish poetry

\section{STRESZCZENIE}

\section{Pomiędzy bąkami a Cafe du Monde: The Prince of the Quotidian Paula Muldoona}

Artykuł koncentruje się na pochodzącym z 1994 roku zbiorze Paula Muldoona The Prince of the Quotidian, traktowanym jako poetycka autobiografia, która czerpie swoją siłę z dwoistego podejścia - do precyzowania doświadczenia z jednej strony, a powtarzalnego (wielokrotnego) multiplikowania jego tekstowej reprezentacji z drugiej strony. Przyjmując wskazówkę z Shibboleth: For Paul Celan Derridy, Autor artykułu dowodzi, że Muldoon tworzy sieć powiązań, w którejfunkcjonuje rozmówca, tym samym stawiając siebie na granicy między dośrodkowym skupieniem na życiu, jakkolwiek przyziemne może być, a odśrodkową tekstualnością, motywowaną przez intertekstualne odniesienia.

\section{Słowa kluczowe}

Paul Muldoon, autobiografia, współczesna poezja irlandzka 